Original Article

\title{
PHARMACOGNOSTICAL GENETIC BARCODING AND PHYTOCHEMICAL ANALYSIS ON LEAVES OF DALBERGIA VOLUBILIS ROXB.-AN EXTRA PHARMACOPOEIAL DRUG OF AYURVEDA
}

\author{
ACHARYA RABINARAYAN*, JANI SWITU, C R HARISHA, SHUKLA VINAY
}

Head of Dravyaguna Department, Room No. 329, $3^{\text {rd }}$ Floor, Institute Building, IPGT and RA, Gujarat Ayurved University, Jamnagar 361008 Email: drrnacharya@gmail.com

Received: 19 Mar 2018 Revised and Accepted: 08 May 2018

\begin{abstract}
Objective: The leaves of Biraskala have been reported for its ethnomedicinal claims for the management of aphthae, heart pain, menorrhagia and post-partum problem. Botanically it has been identified as Dalbergia volubilis Roxb. This research article overcomes the lacuna and explores the anatomical, Deoxyribonucleic acid (DNA) barcoding and preliminary phytochemical analysis including High Performance Thin Layer Chromatography (HPTLC).
\end{abstract}

Methods: After proper authentication, leaves were exposed to macroscopy, microscopy and micrometric analysis and physicochemical, qualitative, quantitative and HPTLC study as per of Ayurvedic Pharmacopoeia of India (API). DNA barcoding of the fresh tender leaves samples were carried out following standard methods.

Results: Macroscopically leaves are compound, unipinnate, imparipinnate, rachis base pulvinus, leaflets 11-13. Microscopy of T. S. of rachis resembles anatomical structure of stem. Schematic outline of T. S. of petiolule is circular in shape with single layer epidermis is followed by ground tissue and centrally located vascular bundle. Schematic outline of T. S. of leaflet is bulged in the center and the extending arms of lamina are linear. Surface study reveals stomatal index to be 33.33 . The genetic barcoding confirms the species $D$. volubilis. Loss on drying was found to be $8.78 \pm 0.57$. HPTLC results shows 6 peaks and 7 peaks at 254 and $366 \mathrm{~nm}$

Conclusion: $D$. volubilis, is a woody climbing unarmed inland shrub with stipules modified into hook and imparipinnately unipinnate compound leaves, are the key field identification character of the plant. Typical microscopical characteristic are presence of solitary crystal mostly embedded in sheath surrounding the vascular bundle and paracyctic type of stomata.

Keywords: Dalbergia volubilis. DNA barcoding, Pharmacognosy, Anukta dravya

(c) 2018 The Authors. Published by Innovare Academic Sciences Pvt Ltd. This is an open access article under the CC BY license (http://creativecommons.org/licenses/by/4.0/] DOI: http://dx.doi.org/10.22159/ijpps.2018v10i6.26074

\section{INTRODUCTION}

Medicinal plants used by traditional healers but not recorded in classical texts of Ayurveda are designated as Namatah Anukta dravya or extra-pharmacopoeial plants [1]. One of such folk plant is Biraskala, used by Tribals of Odisha. The leaves of this plant are used in aphthae [2] and also in heart pain, menorrhagia and post-partum problem [3].

The plant Biraskala is identified as Dalbergia volubilis Roxb. belonging to Fabaceae family. D. volubilis is woody climbing unarmed inland shrub with pinnatified leaves, leaflets ranging from 7-13 and pale blue flowers [4,5]. Review of literature reveals that few work has been reported on Dalbergia genus which includes review on chemical constituents, ethanobotanical claims, pharmacology, biological activities [6, 7], Genetic barcoding of various other species of genus Dalbergia [8], pharmacognostical phytochemical parameters of leaves of Dalbergia sissoo L [9] and anti-diabetic activity [10] has been reported.

Though various parts of plants are used by tribals, the plant is not yet evaluated in a scientific way for its anatomical characters and phytochemical constituent. Hence the leaf of $D$. volubilis has been explored in this article to bring insight on the leaf anatomy, genetic barcoding and preliminary phytochemical constituents including High Performance Thin Layer Chromatography (HPTLC) profile.

\section{MATERIALS AND METHODS}

\section{Chemical and reagents}

Chemicals utilized for pharmacognostical study and phytochemical study including HPTLC were procured from Rankem Mumbai and Analar India. Gallic acid standard was obtained from Loba chemia, Mumbai and Folin-Ciocalteu reagent was procured from SRL, India.
All chemical used for analysis were of laboratory grade and chemical used for HPTLC were of analytical grade.

\section{Collection and authentication}

The plant samples were collected by the corresponding and second author from one of its natural habitat, Gandhamardana hills, Odisha, in month of September 2016 with help of local taxonomist. Herbarium was submitted to Pharmacognosy laboratory authentified by the Pharmacognosist of the institute and provided with herbarium reference no. Phm/6199/2016-17 for further reference. (fig. 1, A-D).

\section{Pharmacognostical study}

Macroscopic observations were made with naked eyes and centimeter scale $(\mathrm{cm})$ was used to measure the leaf length and width. The leaves were washed and transverse sections were taken cleared with chloral hydrate to observe the anatomy of main rachis, petiolule and leaflet with help of Quasmo binocular compound microscope, India. Micro-photographs were taken with help of Kodak easy share C140, 8.2 megapixels $3 \mathrm{x}$ optical/5x digital zoom HD camera. For histochemical tests, the thick transverse sections of the leaf were exposed to Iodine $(2 \mathrm{~g}$ iodine and $3 \mathrm{~g}$ potassium iodide in $100 \mathrm{ml}$ water), Phloroglucinol $(20 \mathrm{mg} / \mathrm{ml}$ alcohol $)$ and Hydrochloric acid $(6 \mathrm{~N})$ for observation of starch grain and lignified tissue.

For powder microscopy, to obtain powder, shaded dried leaves were grounded by mechanical grinder and sieved through $80 \#$.

For micrometry, triplicate reading were recorded and mean value was taken into consideration along with standard deviation based on sample using Microsoft excel. The micrometric values are mentioned in micrometer scale $(\mu \mathrm{m})[11]$. 


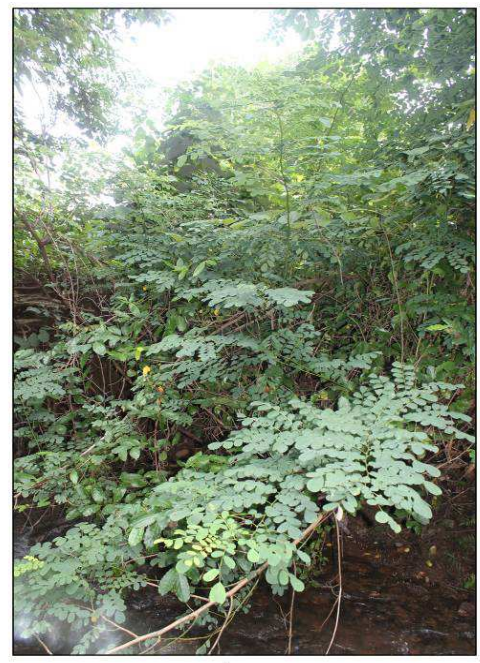

A

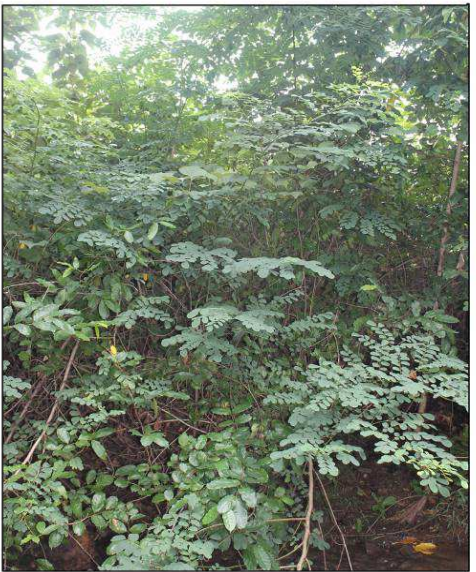

C

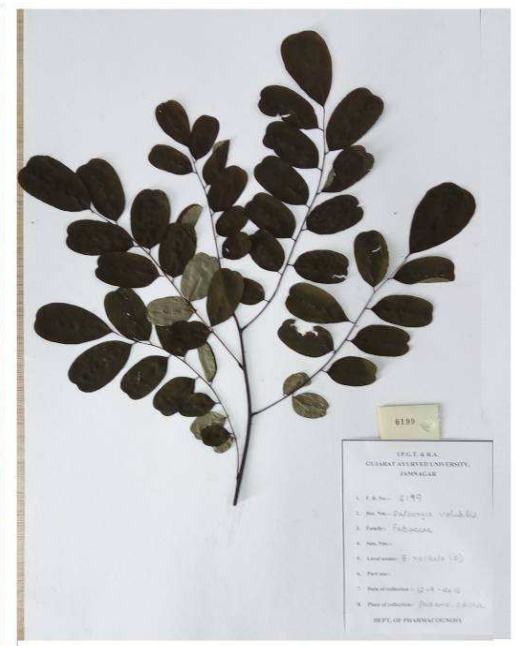

B

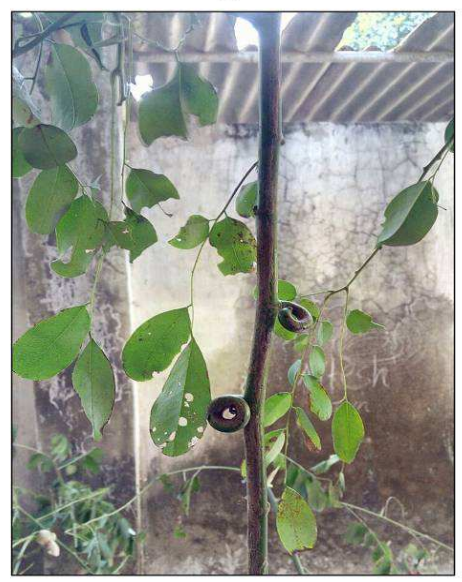

D

Fig. 1: A: Plant in natural habitat, B: Herbarium phm/6199/2016-17, C: The climbing nature of plant in forest, D: Hooks for climbing

\section{DNA barcoding}

The fresh tender leaves were sent to Aristogene Biosciences Private Limited, Bangalore for DNA barcoding. The DNA was isolated from fresh leaf samples using homogenizer, lysis buffer and centrifuged. The supernatant was discarded and pellet was washed and exposed to column purification. The barcoding was based on sequence homology and phylogenic analysis. The forward primer and reverse primer used were 1016_187_011_PCR_6_primer_1_D08. abl and 1016_187_012_PCR_6_PRIMER_2_E08. ab1 respectively.

\section{Physicochemical parameters and qualitative analysis}

The powder of leaf was exposed to physico-chemical i.e. pH, loss on drying, total ash value, acid insoluble ash value, water soluble extractive value and alcohol soluble extractive value, protocols followed as recommended by Ayurvedic pharmacopoeia of India (API). For qualitative analysis, the presence of various secondary metabolites dissolved in water and alcohol extract was done as per reference $[12,13]$.

\section{Quantification of total phenolic content (Folin-Ciocalteu reagent)}

The total phenolic content of the extract was estimated according to the method described by Singleton and Rossi. The concentration of methanolic extracts solution was $10 \mathrm{mg} / 10 \mathrm{ml}$. From this solution, 1 $\mathrm{ml}$ was taken in test tubes and by dilution with same solvent up to $10 \mathrm{ml}$. This is stock solution. From stock solution different concentrations were taken in different test tubes. This same procedure was used for standard. Gallic acid was used as a standard; $1 \mathrm{ml}$ of Folin-Ciocalteu reagent was added in this concentration and the content of the flask was mixed thoroughly and $5 \mathrm{~min}$ later $4 \mathrm{ml}$ of
$20 \%$ sodium carbonate was added, and the mixture was allowed to stand for $30 \mathrm{~min}$ with intermittent shaking. The absorbance of the blue color that developed was read at $765 \mathrm{~nm}$ in UV spectrophotometer. The calculation for unknown concentration of test sample was done by using excel [14].

\section{HPTLC study}

Methonalic extract of leaf was exposed to HPTLC study. The solvent system used for the study is toluene: ethyl acetate (9:1).

\section{Chromatographic conditions}

Application mode was Camag Linomat V, Development Chamberused was of Camag Twin trough Chamber. Precoated Silica $\mathrm{Gel}_{\text {GF254 }}$ plates were used. Chamber Saturation was done for $30 \mathrm{~min}$. Development Time was $30 \mathrm{~min}$. the plate was scanned in Camag Scanner III with Deuterium lamp, Tungstan Lamp as detectors and Win cats software was used for data analysis.

\section{Spray reagent}

$0.5 \mathrm{~g}$ vanillin (Rankem) was dissolved in $100 \mathrm{ml}$ sulphuric acidethanol $(40+10)$ (Rankem, USA). After spraying the plate was heated at $120^{\circ} \mathrm{C}$ until maximum spot colour intensity was reached [15].

\section{RESULTS}

\section{Macroscopy}

Leaves are compound, unipinnate, imparipinnate, rachis measures about 10.1-14.6 cm, rachis base pulvinus, leaflets five pairs and one terminal, measures about $1.2-6 \times 1.1-3.2 \mathrm{~cm}$, leaflets alternate, 
subsessile, obovate to oblong, entire margin, obtuse apex, dark green above, whitish green beneath, petiolule is short and measures about 0.2-0.5 cm. (fig. 2-A, fig. 3-A) On drying, leaves turn brownish black in colour, leaflets withers off and starts to curl gently.

\section{Microscopy}

\section{Transverse section of main rachis}

Schematic outline of T. S. of rachis is somewhat oval to trigonous in shape measures about $2.7 \mu \mathrm{m}$ in length and $2 \mu \mathrm{m}$ in width. Anatomically rachis resembles the stem.

Detailed T. S. of rachis shows single layered epidermis covered with cuticle followed by 4-6 layers of cortical cells containing chlorophyll content, continuous ring of pericyclic fibers is followed by single layer endodermis and radially arranged circular vascular bundle with central wide pith. Vascular bundle consist of phloem situated above xylem, prismatic crystals are embedded in phloem. Phloem consists of phloem fibers and its sieve elements. Xylem consist of meta-xylem towards periphery and proto-xylem towards pith. Xylem consists of xylem parenchyma and its fibers. Pith consist of large parenchyma cells often embedded with rhomboidal and prismatic crystals. Pith occupies around $35-40 \%$ of the transverse section, some of the pith parenchyma cell are lignified and pitted. (fig. 2, B-E)

\section{T. S. of petiolule}

Schematic outline of T. S. of petiolule is circular in shape, measures about $2.7-2.9 \mu \mathrm{m}$ in diameter. Single layer epidermis is followed by ground tissue and centrally located vascular bundle.

Detailed T. S. of petiolule shows single layer epidermal cells covered with cuticle followed by 9-12 layers of ground tissue, made up of parenchyma cells containing chlorophyll and oil globules. The pericyclic sclerenchyma cells are embedded with prismatic and rhomboidal crystals of calcium oxalate. Vascular bundle is arranged in a crescent shape and completely surrounded by continuous collenchymatous ring. Phloem is situated inner towards the collenchyma tissue and made up of phloem fiber and its elements. Xylem consists of meta xylem towards periphery and proto-xylem towards the center and made up of xylem fiber and parenchyma. (fig. 2, F-H)
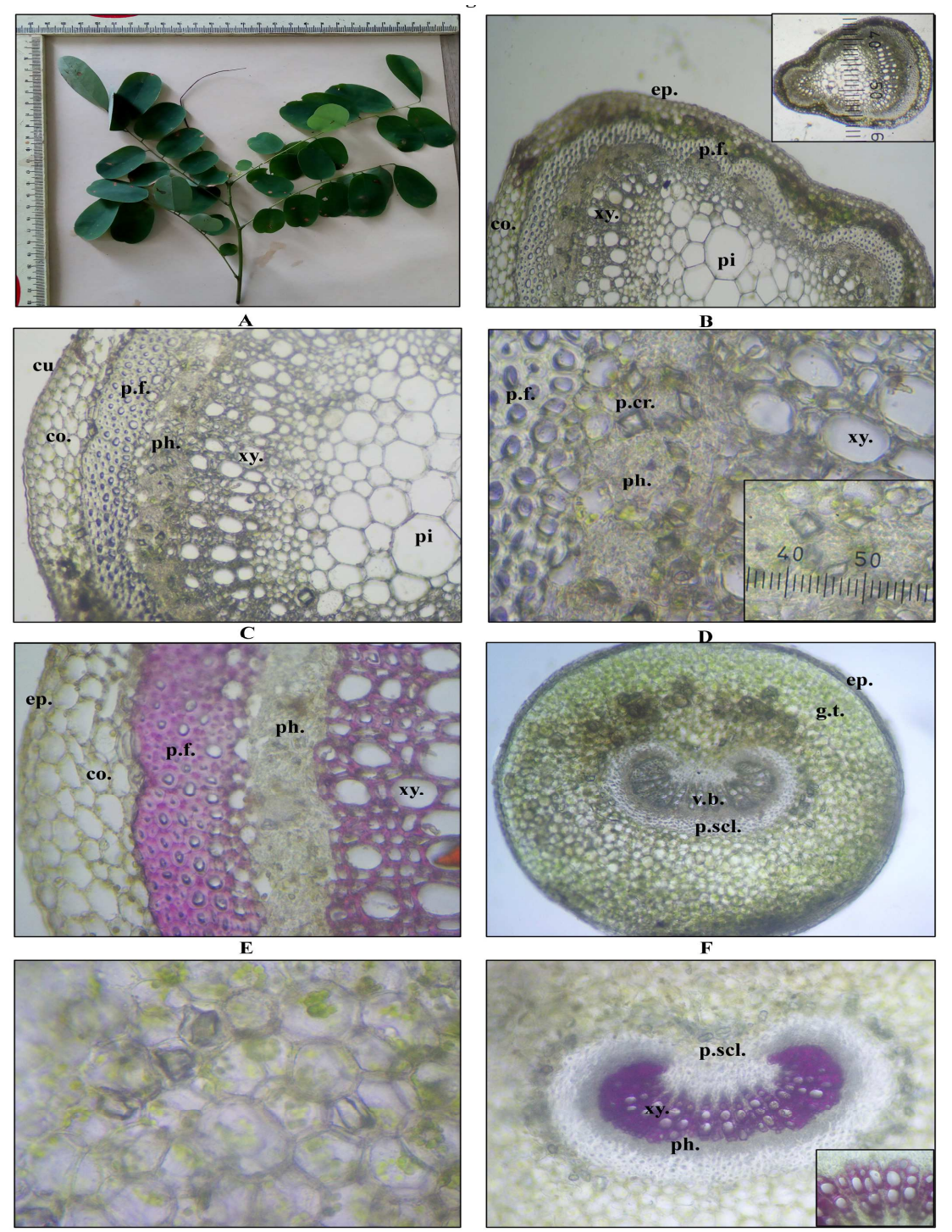

G

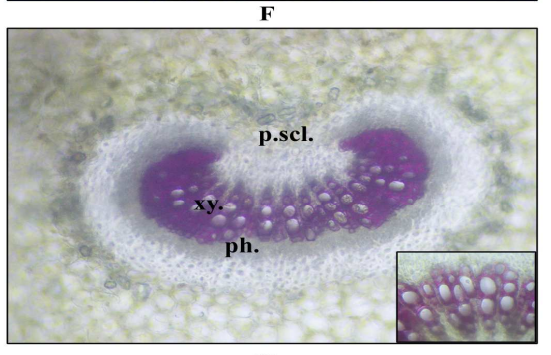

$\mathbf{H}$

Fig. 2: A: Leaf measurement, B: T. S. of Rachis, C: Detailed T. S. of Rachis, D: Presence of prismatic crystals in phloem region, E: T. S. of Rachis (stained) in 40X view, F: T. S. of petiolule G: Presence of rhomboidal crystal in cortex, H: Enlarged view of stained central vascular bundle with Pericylic sclerenchyma, ep.-epidermis, v. b.-vascular bundle, co.-cortex, cu.-cuticle, p. f.-pericyclic fiber, p. cr.-prismatic crystal, xy.-xylem, ph.-phloem, g. t.-ground tissue, p. scl.-periclic sclerenchyma, pi-pith 


\section{T. S. of leaflet}

Schematic outline of T. S. of leaflet is bulged in the center and the extending arms of lamina are linear. T. S. passing through the central vein measure about $1.5 \times 1.2 \mu \mathrm{m}$.

Detailed T. S. of leaflet passing through lamina shows single layered upper and lowered epidermis with cuticle. The epidermal cells of upper epidermis are narrowly barrel shaped whereas the cells of lower epidermis are oval to broadly barrel shaped. Upper and lower epidermis is followed by mesophyll tissue filled with chlorophyll content. Mesophyll is made up of upper single layered elongated palisade and lower loosely arranged 5-6 layers of spongy parenchyma.

T. S. passing through central vein shows both epidermis covered with thin layer of cuticle followed by collenchymatous layer. Collenchyma cells are big and compactly arranged. Centrally located vascular bundle surrounded by bundle sheath. Pericylic fiber surrounds the vascular bundle. Vascular bundle consists of phloem and xylem. Phloem is made up of phloem fiber and sieve elements. Xylem is made up of xylem parenchyma and its fiber, meta-xylem is situated towards the lower epidermis whereas proto-xylem is situated towards the center. (fig. 3, B-F).
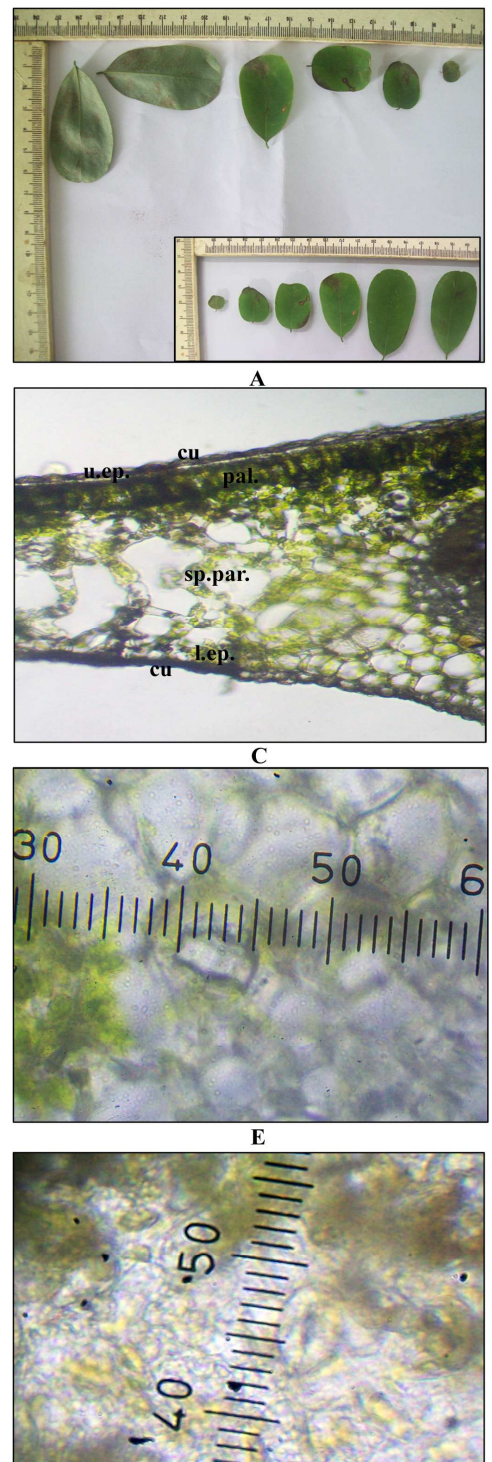

G

\section{Surface and micrometric evaluation}

Surface study of lower epidermis shows presence paracyctic stomata which is absent in case of upper surface. Stomatal index lower surface is $33.33 \pm 0.00$. Stomata measures about $0.6 \pm 0.1$ $\times 0.4 \pm 0.1 \mu \mathrm{m}$. palisade ratio is $1 / 2$. (fig. $3, \mathrm{G}-\mathrm{H}$ )

\section{Powder microscopy}

The organoleptic characters of leaf powder shows brownish green in colour with faint aroma, mild astringent taste and fibrous touch. (fig. 4, A-B).

The diagnostic characters of leaf powder shows presence trichomes, prismatic and rhomboidal crystals of calcium oxalate, fragments of fibers, pleuricellular trichome, starch grain with hilum, fragment of spiral vessel and crystal fiber, epidermal cells in tangential and surface view filled with brown content. (fig. 4, C-L)

\section{DNA barcoding}

The results obtained from Blast results and phylogenetic tree is depicted in table 1 and fig. 5 A respectively.
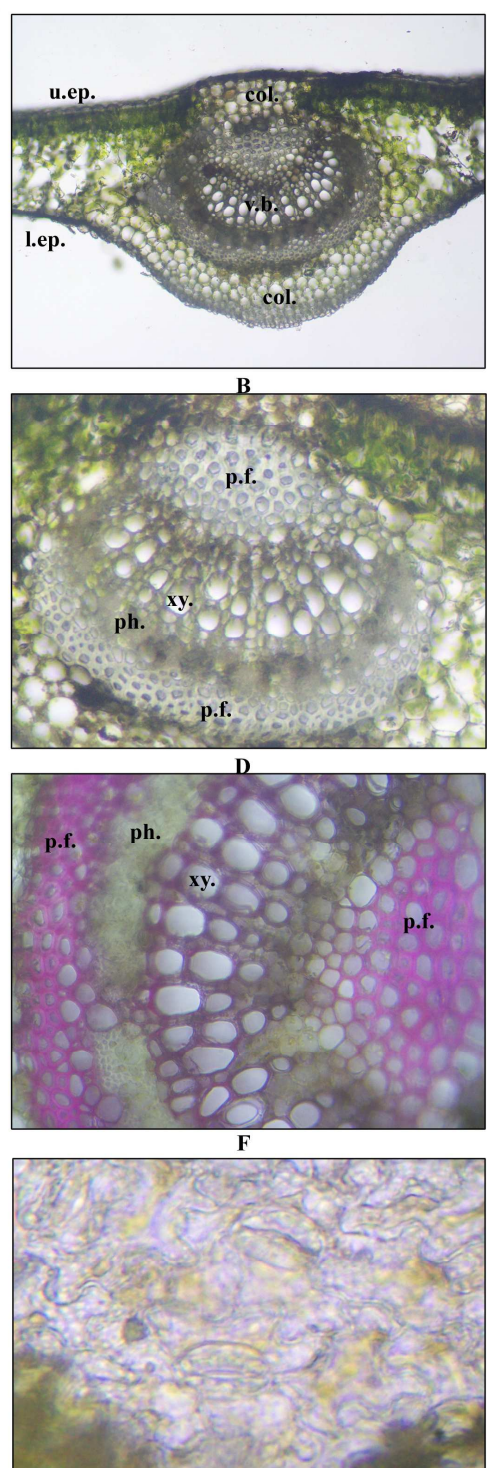

H

Fig. 3: A: Measurement of fresh leaflets with petiolule, B: T. S. of leaf passing through mid rib, C: T. S. of Lamina, D: Enlarged view of vascular bundle, E: Micromeasurement of rhomboidal crystal, F: T. S. of leaf passing through mid-rib (Stained), G: Micromeasurement of stomata (lower surface), H: Paracytic stomata in surface study of lower epidermis, u. ep--upper epidermis, l. ep.-lower epidermis, sp. par.-Spongy parenchyma, xy.-xylem, ph.-phloem, p. f.-pericyclic fiber 


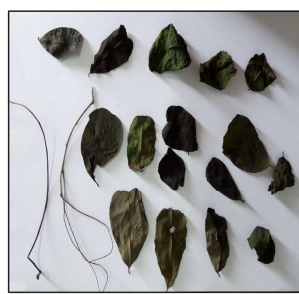

A

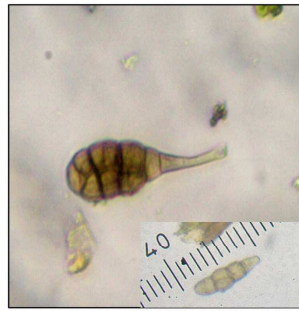

D

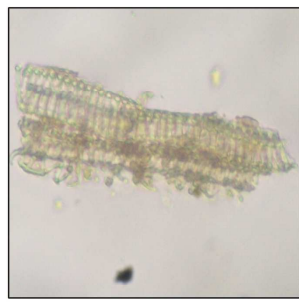

G

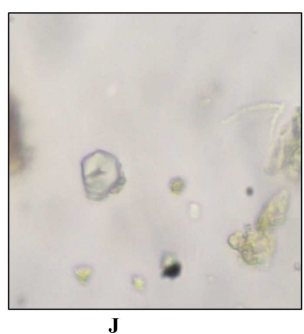

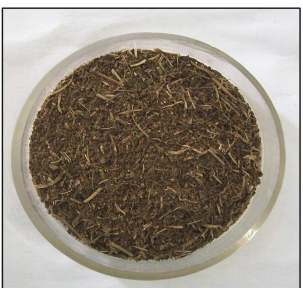

B

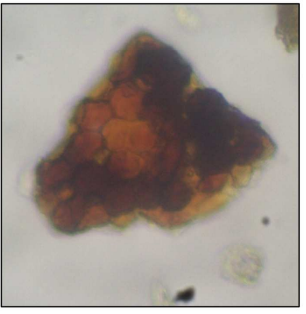

$\mathbf{E}$

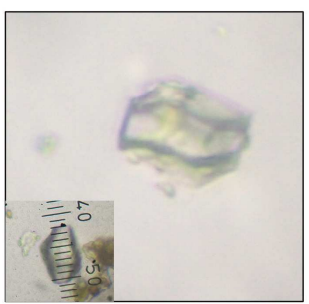

H

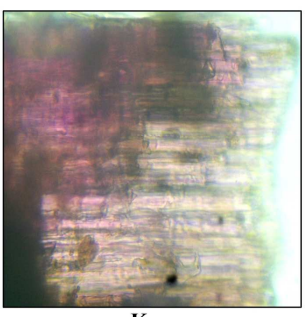

K

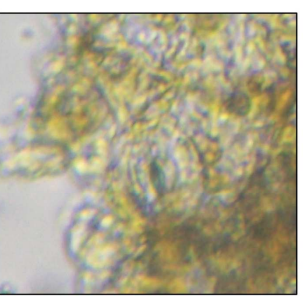

C
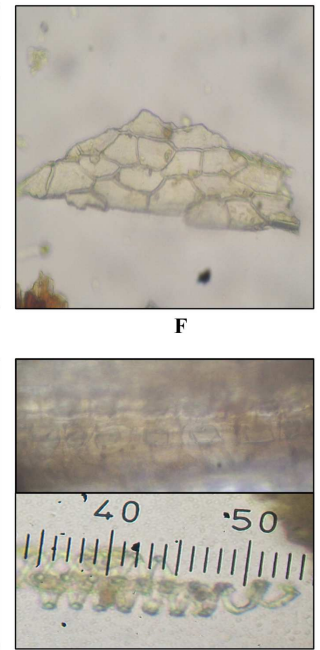

I

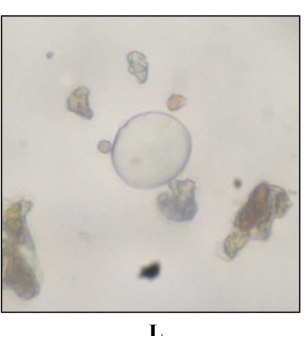

Fig. 4: A: Dry leaves, B: Dried leaf powder, C: Fragment of paracytic stomata, D: Pleuricellular trichome, E: Epidermal cells in surface view filled with brown content F: Epidermal cells in tangential view, G: Fragment of scalariform vessel, H: Micro-measurement of rhomboidal crystal, I: Crystal fiber, micro-measurement of fragment of spiral vessels, J: Simple starch grain with hilum, K: Fragment of lignified group of fibers, L: Oil globule

Table 1: Sequences producing significant alignments through BLAST analysis

\begin{tabular}{|c|c|c|c|c|c|c|}
\hline Description & $\begin{array}{l}\text { Max } \\
\text { score }\end{array}$ & $\begin{array}{l}\text { Total } \\
\text { score }\end{array}$ & $\begin{array}{l}\text { Query } \\
\text { cover }\end{array}$ & E value & Ident & Accession \\
\hline $\begin{array}{l}\text { Dalbergia sp. } 8 \text { IH-2015 voucher C38 ribulose-1,5-bisphosphate } \\
\text { carboxylase/oxygenase large subunit (rbcL) gene, partial cds; chloroplast }\end{array}$ & 514 & 514 & $76 \%$ & $9 e-142$ & $89 \%$ & KM676477.1 \\
\hline $\begin{array}{l}\text { Dalbergia sp. } 2 \text { IH-2015 voucher AAU1565 ribulose-1,5-bisphosphate } \\
\text { carboxylase/oxygenase large subunit (rbcL) gene, partial cds; chloroplast }\end{array}$ & 514 & 514 & $76 \%$ & $9 e-142$ & $89 \%$ & KM676469.1 \\
\hline $\begin{array}{l}\text { Dalbergia stipulacea voucher K3555 ribulose-1,5-bisphosphate } \\
\text { carboxylase/oxygenase large subunit (rbcL) gene, partial cds; chloroplast }\end{array}$ & 514 & 514 & $76 \%$ & $9 e-142$ & $89 \%$ & KM510303.1 \\
\hline $\begin{array}{l}\text { Dalbergia stipulacea voucher C2995 ribulose-1,5-bisphosphate } \\
\text { carboxylase/oxygenase large subunit (rbcL) gene, partial cds; chloroplast }\end{array}$ & 514 & 514 & $76 \%$ & $9 e-142$ & $89 \%$ & KM510301.1 \\
\hline $\begin{array}{l}\text { Dalbergia oliveri voucher C36 ribulose-1,5-bisphosphate } \\
\text { carboxylase/oxygenase large subunit (rbcL) gene, partial cds; chloroplast }\end{array}$ & 514 & 514 & $76 \%$ & $9 e-142$ & $89 \%$ & KM510286.1 \\
\hline $\begin{array}{l}\text { Dalbergia oliveri voucher E2 } 153 \text { ribulose-1,5-bisphosphate } \\
\text { carboxylase/oxygenase large subunit (rbcL) gene, partial cds; chloroplast }\end{array}$ & 514 & 514 & $76 \%$ & $9 e-142$ & $89 \%$ & KM510285.1 \\
\hline $\begin{array}{l}\text { Dalbergia oliveri voucher E5841 ribulose-1,5-bisphosphate } \\
\text { carboxylase/oxygenase large subunit (rbcL) gene, partial cds; chloroplast }\end{array}$ & 514 & 514 & $76 \%$ & $9 e-142$ & $89 \%$ & KM510284.1 \\
\hline $\begin{array}{l}\text { Dalbergia oliveri voucher C13 ribulose-1,5-bisphosphate } \\
\text { carboxylase/oxygenase large subunit (rbcL) gene, partial cds; chloroplast }\end{array}$ & 514 & 514 & $76 \%$ & $9 e-142$ & $89 \%$ & KM510283.1 \\
\hline $\begin{array}{l}\text { Dalbergia oliveri voucher C } 915 \text { ribulose-1,5-bisphosphate } \\
\text { carboxylase/oxygenase large subunit (rbcL) gene, partial cds; chloroplast }\end{array}$ & 514 & 514 & $76 \%$ & $9 e-142$ & $89 \%$ & KM510282.1 \\
\hline $\begin{array}{l}\text { Dalbergia oliveri voucher L } 2153 \text { ribulose-1,5-bisphosphate } \\
\text { carboxylase/oxygenase large subunit (rbcL) gene, partial cds; chloroplast }\end{array}$ & 514 & 514 & $76 \%$ & $9 e-142$ & $89 \%$ & KM510254. \\
\hline
\end{tabular}




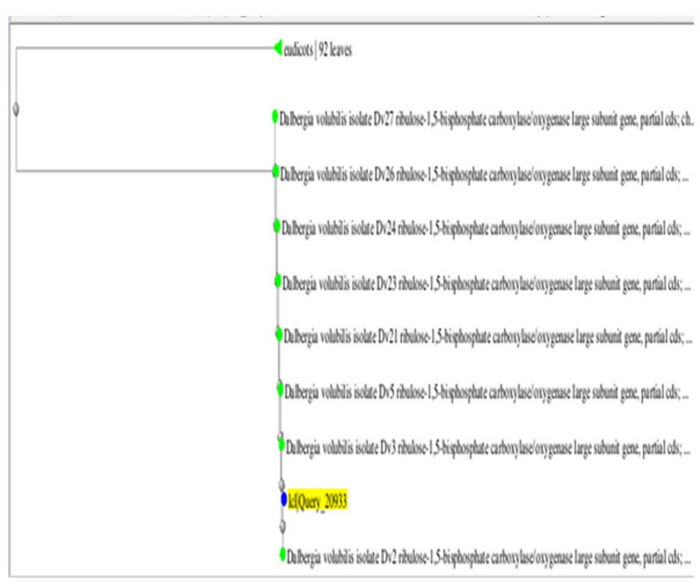

A

Fig. 5: A: The phylogenetic tree pattern physicochemical analysis
The leaf powder was found to be devoid of any foreign matter. The other physicochemical parameters are given in table 2 .

\section{Qualitative tests}

Qualitative test revealed presence of carbohydrate, alkaloids and tannin in aqueous as well as methanolic extract of leaf. The results of tests performed are depicted in table 3 .

\section{Quantitative}

The total phenolics content of methonalic extract of $D$. volubilis calculated as gallic acid equivalent of phenols was detected. The details of absorbance and concentration of standard as well as samples are given in table 4 . The linear graph was obtained in standard and $\mathrm{R}^{2}$ was found to be 0.989 . The concentration is 0.221 $\mu \mathrm{g} / \mathrm{ml}$ in methanolic extract of leaf.

\section{HPTLC}

The methanol extract of leaf shows 6 peaks, 7 peaks and 8 peaks at UV Vis range of $254 \mathrm{~nm}, 366 \mathrm{~nm}$ and $600 \mathrm{~nm}$ respectively. After spraying with spray reagent leaf shows 8 peaks at $366 \mathrm{~nm}$. The $R_{f}$ values are mentioned in table 5 . The photos of HPTLC plate, $3 \mathrm{~d}$ graphs and peak display at UV-VIS range is depicted in fig. 6

Table 2: Physicochemical parameters of Dalbergia volubilis Roxb leaves

\begin{tabular}{lll}
\hline S. No. & Parameters & Results (\%W/W)\# \\
\hline 1. & Loss on drying & $8.78 \pm 0.57$ \\
2. & Total ash value & $5.58 \pm 0.34$ \\
3. & Acid insoluble ash value & $0.52 \pm 0.05$ \\
4. & Water extractive value & $10.37 \pm 0.64$ \\
5. & Alcohol extractive value & $14.33 \pm 0.40$ \\
\hline
\end{tabular}

\# Values are means of three independent analysis \pm standard deviation

Table 3: Results of Qualitative analysis Dalbergia volubilis Roxb leaves

\begin{tabular}{|c|c|c|c|}
\hline S. No. & Tests & Water extract & Alcohol extract \\
\hline 1. & Molisch's test & $+\mathrm{ve}$ & $+\mathrm{ve}$ \\
\hline 2. & Fehling test & -ve & -ve \\
\hline 3. & Dragendroff test & + ve & $+\mathrm{ve}$ \\
\hline 4. & Hagger's test & -ve & + ve \\
\hline 5. & Wagner's test & +ve & $+\mathrm{ve}$ \\
\hline 6. & Biuret & -ve & -ve \\
\hline 7. & Ninhydrin test & -ve & -ve \\
\hline 8. & Iodine test & -ve & -ve \\
\hline 9. & Neu. Ferric chloride & + ve & + ve \\
\hline 10. & Lead acetate & + ve & $+\mathrm{ve}$ \\
\hline 11. & Seliwenoff's test & -ve & -ve \\
\hline 12. & Salkowski test & -ve & $+\mathrm{ve}$ \\
\hline 13. & Shinoda test & -ve & -ve \\
\hline 14. & Vanillin+sulphuric acid & -ve & $+\mathrm{ve}$ \\
\hline
\end{tabular}

'+ve'-presence, '-ve'-absence

Table 4: Absorbance $(765 \mathrm{~nm})$ at various concentrations $(\mu \mathrm{g} / \mathrm{ml})$ of standard (gallic acid) and test drug in total phenolic content

\begin{tabular}{lll}
\hline S. No. & Concentration $(\boldsymbol{\mu g} / \mathbf{m l})$ & Absorbance $(\mathbf{n m})$ Std. and sample \\
\hline 1. & 25 & 0.676 \\
2. & 50 & 1.263 \\
3. & 75 & 1.82 \\
4. & 100 & 2.184 \\
5. & D. volubilis leaf & 0.271 \\
\hline
\end{tabular}

Table 5: Rfvalues obtained at UV and visible range of Dalbergia volubilis Roxb. leaves

\begin{tabular}{|c|c|c|c|c|}
\hline S. No. & $R_{\mathrm{f}}$ at $254 \mathrm{~nm}$ & $R_{\mathrm{f}}$ at $366 \mathrm{~nm}$ & After spray (366 nm) & Visible $(600 \mathrm{~nm})$ \\
\hline 1 & 0.01 & 0.01 & 0.01 & 0.01 \\
\hline 2 & 0.36 & 0.07 & 0.12 & 0.13 \\
\hline 3 & 0.68 & 0.13 & 0.29 & 0.30 \\
\hline 4 & 0.72 & 0.29 & 0.44 & 0.44 \\
\hline 5 & 0.84 & 0.48 & 0.48 & 0.48 \\
\hline 6 & 0.96 & 0.94 & 0.81 & 0.81 \\
\hline 7 & - & 0.96 & 0.94 & 0.84 \\
\hline 8 & - & - & 0.98 & 0.94 \\
\hline
\end{tabular}



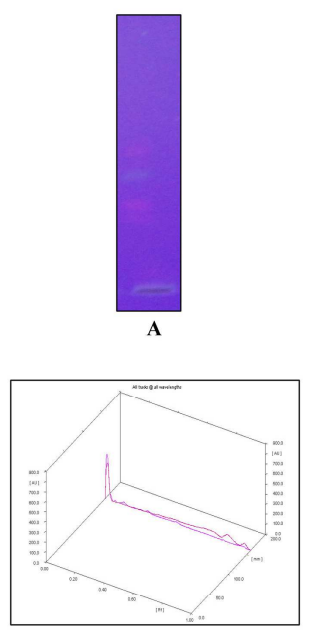

D

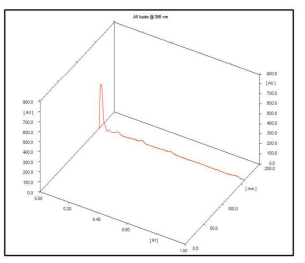

G

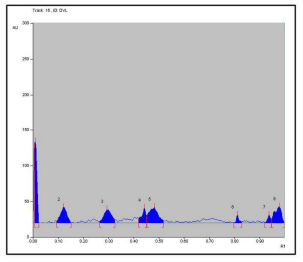

J
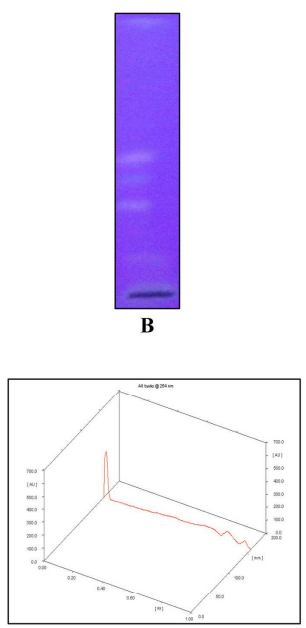

E

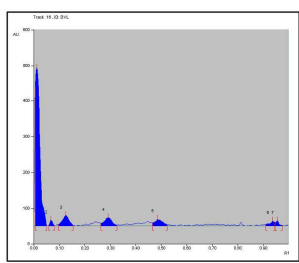

H

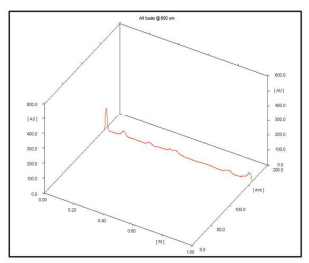

K
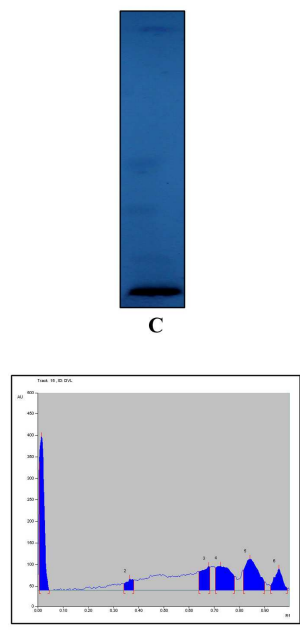

F

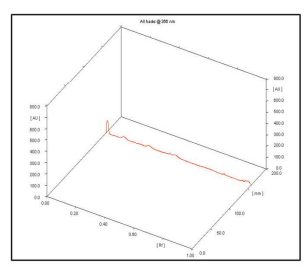

I

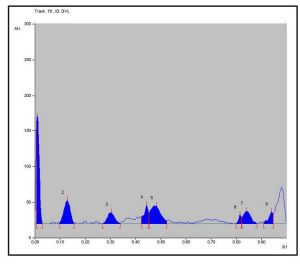

Fig. 6: A: HPTLC plate of leaf at $366 \mathrm{~nm}$ (before spray), B: HPTLC plate of leaf at $366 \mathrm{~nm}$ (after spray), C: HPTLC plate of leaf at $600 \mathrm{~nm}$, D: 3 d graph at UV-VIS range, E: All tracks 3 d graph at $254 \mathrm{~nm}$, F: Peak display at $254 \mathrm{~nm}, \mathrm{G:} 3 \mathrm{~d}$ graph at $366 \mathrm{~nm}$, H: Peak display at $366 \mathrm{~nm}$, I: 3 d graph at366 nm after spray, J: Peak display after spray at $366 \mathrm{~nm}$, K: 3 d graph at $600 \mathrm{~nm}$, L: Peak display at $600 \mathrm{~nm}$

\section{DISCUSSION}

Dalbergia volubilis Roxb. is a hard, climbing unarmed shrub with stipules modified into hook for climbing. Leaves are compound imparipinnately unipinnate which is key character for identification. Presence of solitary prismatic crystal and some cells of lower and upper epidermis in leaf have papillose and mucilage containing cells are one of the important anatomical character of Dalbergia genus. Stomata in lower epidermal cells are mostly of Rubiaceous type i.e. paracyctic which is a key identifying character of Dalbergia genus. In T. S. of petiolule, the concentration of rhomboidal crystals are found mostly accompanying the vascular bundle and the crystalliferous cells frequently form sheath along the outer boundary of Pericylic sclerenchyma also depicts key character of Dalbergia genus.[16] The results from BLAST analysis shows significant match with Dalbergia volubilis isolate Dv27,26,24,23,21,5,3 and 2 ribulose 1,5-biphosphate carboxylase oyygenase large subunit gene providing correct genetic coding for confirmation the plant $D$. volubilis Roxb. The results obtained from physicochmeical parameter, qualitative, quantitative and HPTLC study will serve as standardization values providing information regarding the purity of the plant $D$. volubilis Leaf.

\section{CONCLUSION}

Dalbergia volubilis Roxb. is a woody climbing unarmed inland shrub with stipules modified into hook the key field identification character of the plant. Typical characteristic of $D$. volubilis leaf is presence of solitary crystal mostly embedded in sheath surrounding the vascular bundle, paracyctic type of stomata and presence of pleuricellular trichomes. DNA barcoding study gives the information regarding the genetic classification of the Dalbergia volubilis Roxb. Physicochemical results, HPTLC results will help in further standardization and act as standards for quality assurance.

\section{ACKNOWLEDGMENT}

We would like to thank Director of IPGT and RA, Gujarat Ayurved University Jamnagar and Ministry of AYUSH, Government of India, for funding the project and all the supporting laboratory heads and staff members of IPGT and RA. We would like to extend our thanks to Aristogene Biosciences Private Limited..

\section{AUTHORS CONTRIBUTIONS}

All the authors have contributed for carrying out the DNA barcoding study in this article equally. The first and second authors have designed the concept conducted the experimental studies, data acquisition, data analysis, statistical analysis and manuscript preparation under the guidance of other contributing authors. All authors have incorporate concept, design, definition of intellectual content, editing and reviewing of the manuscript.

\section{CONFLICT OF INTERESTS}

Declared none 


\section{REFERENCES}

1. Anonyumous an appraisal of tribal folk medicines, CCRAS, New Delhi. $1^{\text {st }}$ edi. 1999. p. 1-2.

2. Khare CP. Indian medicinal plants (an illustrated dictionary). Berlin (Germany): Springer publishers; 2007. p. 201.

3. Koteswara RJ, Seetharami RTVV, Aniel KO. Ethnomedicine of the Gadabas, a primitive tribe of Visskhapatnam District, Andra Pradesh. Internat Multidiscipl Res J 2011:10-4.

4. Brahmam M, Saxena HO. Flora of Orissa. Vol. I. Orissa: Regional Research Laboratory; 1994. p. 522.

5. Gamble JS. Flora of the presidency of Madras. Vol. I. Dehradun: Bishensingh, Manhendra Pal Singh; 2011. p. 522.

6. Neeru V, Manisha V, Sharma SK, Satish S. Chemistry and biological activities of the genus Dalbergia a review. Pharmacogn Rev 2009;3:307-19.

7. Sanjib S, Jamil AS, Himangsu M, Faroque $H$, Anisuzzman, Mahadhi $\mathrm{H}$, et al. Ethnomedicinal, phytochemical, and pharmacological profile of the genus Dalbergia L.(Fabaceae). Phytopharmacology 2013:291-346.

8. Ida H, Mihaly C, Erik DK, Lene RN, Ida T. The use of DNA barcoding in identification and conservation of rosewood
(Dalbergia spp.). Plos One 2015. Doi:10.1371/journal. pone.0138231.

9. Josephin NR, Venkatarathnakumar T, Ajitha DA, Gowri R, Parameshwari $\mathrm{R}$, Shanthi $\mathrm{M}$, et al. Pharmacognostic and preliminary phytochemical evaluation of the leaves of Dalbergia sissoo roxb. Asian J Pharm Clin Res 2012(5, Suppl 3):115-9.

10. Pankaj SN, Dharmendra S, Kiran P, Jain SK. Antidiabetic activity of ethanolic extract of Dalbergia sissoo L. leaves in alloxan induced diabetic rats. Int J Chem Pharm Res 2010;2:24-7.

11. Trease and Evans. Pharmacognosy. $16^{\text {th }}$ ed. London: Saunders Elsevier; 2009. p. 567-68.

12. Anonymous. The Ayurvedic Pharmacopoeia of India. Part-II. Vol-II. 1st ed. New Delhi: Government of India, Ministry of Health and Family Welfare, Department of AYUSH; 2008.

13. Khandelwal KR. Practical pharmacognosy. 19th ed. Pune: Nirali Prakashan; 2008. p. 149.

14. Pankaj BN, Nayan RB, Vinay JS, Rabinarayan A, Mukesh BN. In vitro evaluation of antioxidant activity of Cordia dichotoma (Forst f.) bark. AYU; 2013. p. 124-8.

15. Egon S. Thin layer chromatography. Berlin (Germany): Springer Publication; 1969.

16. Metcalfe CR, Chalk L. Anatomy of the Dicotyledons. Vol. I. Great Britain: Oxford university Press. 1950. p. 502-10. 